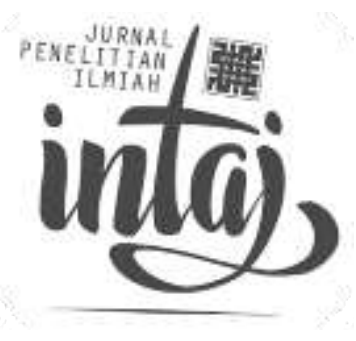

\title{
PEMBERDAYAAN MASYARAKAT DALAM PENGEMBANGAN PENDIDIKAN KARAKTER REMAJA ISLAM \\ DI PRINGU BULULAWANG MALANG
}

Evi Nurhalimah (evihalimah379@gmail.com)

Institut Agama Islam (IAI) AI-Qolam M alang

(Received: Februari 2018 / Revised: Februari 2018 / Accepted: Maret 2018)

\begin{abstract}
The concern of the nation that is experiencing crisis in various aspects of life makes the role of education especially in schools questionable. However, it can not be assessed so because in realizing the purpose of education in addition to the role of the school there is also the role of family and society. Pringu Bululawang $\mathrm{M}$ alang is a village with a majority of the moslem population, but they still have not done their duty as moslem well. Along with the development of Islam in Pringu, this condition began to change marked by the emergence of awareness of carrying out obligations as moslem. These development can be seen, among others, by the existence of various Islamic educational activities implemented to develop the character of Islamic teenagers there. Leaders and community leaders, as well as citizens of the community seemed enthusiastic to support and develop the education of youth I slamic character there.
\end{abstract}

The result of the research found that; (1) the community empowerment mapping strategy undertaken is area mapping, problems, potential, infrastructure suggestions, and character education; (2) community empowerment planning strategy that is carried out is the formation of 
the board, the formulation of the problem handling program, the exploration of empowerment potential, the utilization of village facilities and the house of the citizens, the inculcation of character education value; (3) management strategy undertaken is routine meetings, social ization of the program, making the community as a source of development, utilization of village facilities, the inculcation of character values through religious and social activities.

Keywords: Community Empowerment, Education Development, Character

\section{PENDAHULUAN}

Pada dasarnya, manusia lahir dengan karakter yang fitrah. Kemurnian karakter manusia dapat dengan mudah terkontaminasi oleh pengalaman yang diterima dari lingkungannya, baik lingkungan keluarga, masyarakat sekitarnya, bahkan sistem yang mendukung seseorang menjadi pribadi yang kehilangan karakternya. Maka dari itu, kemurnian karakter tersebut perlu dijaga dengan adanya pendidikan karena pendidikan merupakan sarana menjaga dan mengembangkan fitrah karakter manusia. Rasulullah SAW bersabda:

$$
\text { كل مولود يولد على الفطرة (رواه البخاري و مسلم) }
$$

Artinya: setiap bayi dilahirkan dalam keadaan fitrah. (HR. Bukhari dan M uslim) $\mathrm{Hal}$ tersebut juga telah tertuang dalam Undang-Undang Sistem Pendidikan Nasional (sisdiknas). Di dalam Bab II Pasal 3 UU Sisdiknas tersebut disebutkan:

"Pendidikan nasional berfungsi mengembangkan kemampuan dan membentuk watak serta peradaban bangsa yang bermartabat dalam rangka mencerdaskan kehidupan bangsa, bertujuan untuk berkembangnya potensi peserta didik agar menjadi manusia yang beriman dan bertakwa kepada Tuhan Yang Maha Esa, berakhlak mulia, sehat, berilmu, cakap, kreatif, mandiri, dan menjadi warga negara yang demokratis serta bertanggung jawab".

Dari keterangan di atas, sangat jelas bahwa pembentukan karakter merupakan salah satu tujuan dari pendidikan nasional. Artinya, bahwa pendidikan nasional tidak hanya bertitik berat pada kecerdasan intelektual saja, melainkan juga mengarah kepada pembentukan karakter peserta didik. Pendidikan juga tidak hanya sekedar pelaksanaan proses belajar mengajar untuk memperoleh kecerdasan 
siswa tetapi juga harus mengembangkan potensi lain yang dimiliki oleh peserta didik agar mereka memiliki karakter yang positif.

Akan tetapi, akhir-akhir ini keprihatinan bangsa yang dilanda krisis dalam berbagai aspek kehidupan membuat peran pendidikan khususnya di sekolahsekolah dipertanyakan. Dunia pendidikan khususnya di sekolah-sekolah akhirakhir ini mendapat kritikan bahwa pendidikan belum berhasil membangun Indonesia yang berkarakter. Bahkan tidak sedikit yang mengatakan pendidikan telah gagal karena banyak lulusan sekolah atau sarjana yang cerdas tetapi bermoral lemah.

Namun, tidak bisa dengan mudah dinilai demikian. Hal tersebut karena dalam praktiknya banyak aspek dan pihak yang terlibat dalam upaya mencapai tujuan pendidikan. Dalam mewujudkan tujuan pendidikan tidak hanya didominasi oleh sistem sekolah, tapi juga peran keluarga dan masyarakat di sekitarnya. Untuk memenuhi tanggung jawab tersebut maka tidak hanya sekolah yang diberi kesempatan untuk berpartisipasi terhadap pendidikan, akan tetapi keluarga dan masyarakat harus diikutsertakan. M asyarakat diberikan peluang untuk ikut serta membina dan mencerdaskan anak bangsa, membentuk dan mengembangkan karakter anak bangsa. Oleh karena itu, perlu ada pemberdayaan masyarakat dalam pengembangan karakter anak bangsa tersebut. $\mathrm{Hal}$ itu dilakukan agar tidak hanya satu pihak yang bertanggung jawab terhadap pendidikan, sehingga hasilnya kurang sesuai dengan tujuan pendidikan yang sebenarnya dan telah diatur oleh pemerintah.

Desa Pringu Kecamatan Bululawang Kabupaten Malang merupakan sebuah desa dengan mayoritas penduduknya beragama Islam. Namun, mereka belum melaksanakan akan kewajiban sebagai seorang muslim secara sempurna. $\mathrm{H}$ al ini ini dibuktikan ketika waktu sholat, hampir semua tempat ibadah hanya diisi dengan orang-orang yang usianya sudah udzur. Apalagi dalam melaksanakan kewajiban lainnya mereka masih belum menjalankan secara baik.

Namun, seiring dengan perkembangan Islam di Desa Pringu, saat ini sudah mulai ada perubahan-perubahan dalam hal munculnya kesadaran melaksanakan ajaran Agama Islam dengan baik. $\mathrm{Hal}$ ini dibuktikan dengan adanya fenomena pemberdayaan masyarakat dalam mengembangkan pendidikan karakter remaja Islam di Desa Pringu Bululawang M alang. Pengembangan tersebut terlihat antara 
lain dengan adanya berbagai kegiatan pendidikan yang dilaksanakan oleh masyarakat Pringu untuk mengembangkan karakter remaja Islam di sana.

Pelaksanaan kegiatan pendidikan tersebut tidak lepas dari peran berbagai pemimpin dan tokoh masyarakat. Begitu pula dengan warga masyarakatnya, mereka juga terlihat antusias dalam mendukung dan mengembangkan pendidikan bagi remaja di sana. Dalam kegiatan pendidikan tersebut, terlihat bahwa masyarakat Pringu turut serta dalam mengembangkan pendidikan karakter remaja Islam di desanya. Dilihat dari permasalahan tersebut, masalah yang ingin dijawab dalam penelitian ini adalah bagaimana pemberdayaan masyarakat dalam pengembangan pendidikan karakter remaja Islam di Desa Pringu Bululawang Malang.

Untuk mengetahui pemberdayaan masyarakat dalam pengembangan pendidikan karakter remaja Islam, penulis melakukan penelitian dengan menggunakan metode observasi, interview, dan dokumentasi. Sedangkan untuk menganalisisnya penulis menggunakan pendekatan deskriptif kualitatif terhadap hasil wawancara, observasi, dan dokumentasi.

Adapun fokus penelitian ini diarahkan pada:

a) Strategi pemetaan pemberdayaan masyarakat dalam pengembangan pendidikan karakter remaja Islam di Pringu Bululawang $M$ alang,

b) Strategi perencanaan pemberdayaan masyarakat dalam pengembangan pendidikan karakter remaja Islam di Pringu Bululawang $M$ alang.

\section{METODE PENELITIAN}

Penelitian ini dilakukan di Malang yaitu di Desa Pringu Bululawang Malang Penelitian merupakan penelitian lapangan yang bersifat deskriptif kualitatif. Menurut Denzin dan Lincoln, penelitian kualitatif adalah penelitian yang menggunakan latar alamiah, dengan maksud menafsirkan fenomena yang terjadi dan dilakukan dengan jalan melibatkan berbagai metode yang ada. Adapun menurut Moleong, penelitian kualitatif ini dimaksudkan untuk memahami fenomena tentang apa yang dialami oleh subjek penelitian itu sendiri, misalnya perilaku, persepsi, motivasi, tindakan dan lain-lain. Secara holistik, dengan cara 
deskripsi dalam bentuk kata-kata dan bahasa, pada suatu konteks khusus yang alamiah dan dengan memanfaatkan berbagai metode alamiah. ${ }^{1}$

Dalam mengkaji tentang pemberdayaan masyarakat dalam pengembangan pendidikan karakter remaja Islam di Desa Pringu Bululawang $M$ alang ini, penulis memahami realitas empirik dari fenomena-fenomena yang muncul untuk difahami dan dimaknai berdasarkan interpretasi penulis. Dalam memaknai dan menginterpretasikan data dan informasi, penulis menggunakan referensi untuk dijadikan acuan atau sandaran dan penguat data yang ditemukan di lapangan.

Dalam penelitian ini yang pertama kali dilakukan adalah survey awal dan pembuatan izin untuk penelitian di Pringu Kabupaten Malang. Kemudian dilanjutkan dengan pengambilan data tentang latar belakang obyek penelitian. Adapun metode pengumpulan data yang digunakan adalah metode wawancara, dokumentasi dan observasi. Data-data yang diambil meliputi pemetaan pemberdayaan masyarakat, perencanaan pemberdayaan masyarakat, dan pengelolaan pemberdayaan masyarakat. Selanjutnya, peneliti mengadakan wawancara dengan kepala desa, perangkat desa, tokoh masyarakat, serta tokoh agama. Data-data yang diambil adalah Strategi pemetaan pemberdayaan masyarakat, Strategi perencanaan pemberdayaan masyarakat, dan Strategi pengelolaan pemberdayaan masyarakat.

Sumber data pada penelitian pemberdayaan masyarakat dalam pengembangan pendidikan karakter remaja I slam Pringu Bululawang M alang ini antara lain:

a) Narasumber atau informan. Dalam penelitian pemberdayaan masyarakat terkait pengembangan pendidikan karakter remaja Islam Pringu Bululawang Malang ini narasumber atau informannya adalah kepala desa, perangkat desa, tokoh masyarakat, tokoh agama serta pihak yang dianggap terlibat dalam pemberdayaan masyarakat terkait pengembangan pendidikan karakter remaja Islam. Alasan ditetapkannya informan tersebut, pertama mereka sebagai pelaku yang terlibat langsung dalam memberdayaan masyarakat terkait pengembangan pendidikan karakter remaja Islam. Kedua, mereka mengetahui secara langsung persoalan yang akan dikaji oleh peneliti. Ketiga, mereka lebih menguasai berbagai

\footnotetext{
${ }^{1}$ Lexy J. Moleong, Metodologi Penelitian Kualitatif, (Bandung: PT Remaja, Rosdakarya. 2007), hlm. 5-6
} 
informasi secara akurat berkenaan dengan pemberdayaan masyarakat dalam pengembangan pendidikan karakter remaja I slam.

b) Peristiwa atau aktivitas. Peristiwa atau aktivitas yang menjadi sumber data dalam penelitian pemberdayaan masyarakat terkait pengembangan pendidikan karakter remaja Islam Pringu Bululawang Malang ini adalah pelaksanaan pengelolaan pemberdayaan masyarakat dan pelaksanaan pendidikan karakter remaja Islam di lokasi tersebut.

c) Tempat atau lokasi. Menurut Masykuri, tempat atau lokasi juga bisa dimanfaatkan sebagai salah satu narasumber. ${ }^{2}$ Dari pemahaman lokasi serta lingkungan, peneliti akan mencoba mengkaji dan secara kritis menarik kemungkinan kesimpulan yang berkaitan dengan permasalahan penelitian. Dalam hal ini tempat atau lokasi yang dimaksud adalah tempat atau lokasi kegiatan pemberdayaan dan pendidikan karakter di masyarakat. A dapun lokasi tersebut antara lain Pesantren M iftahul Huda, M asjid N urul H uda A I Jailani dan pemukiman warga desa Pringu Bululawang M alang.

d) Dokumen dan arsip. Dalam penelitian pemberdayaan masyarakat terkait pengembangan pendidikan karakter remaja Islam di Pringu Bululawang Malang ini dokumen yang bisa dijadikan sumber data antara lain kondisi desa, kondisi dan ciri geologis wilayah, sejarah desa, demografi atau data kependudukan, visi misi, tujuan, strategi dan kebijakan, kondisi pemerintahan desa, dan pendidikan serta data-data lain yang dinilai berpengaruh terhadap hal yang diteliti.

Adapun teknik pengumpulan data yang digunakan dalam penelitian ini adalah interview, observasi dan dokumentasi. Interview atau wawancara. Menurut M oleong, wawancara adalah percakapan dengan maksud tertentu. Percakapan itu dilakukan oleh dua pihak, yaitu pewawancara (interviewer) yang mengajukan pertanyaan dan terwawancara (interviewee) yang memberikan jawaban atas pertanyaan itu. Wawancara dibedakan menjadi tiga macam didasarkan atas pertanyaannya, yaitu wawancara pembicaraan informal, pendekatan menggunakan petunjuk umum wawancara, dan wawancara baku terbuka.

\footnotetext{
${ }^{2}$ Masykuri Bakri, Pemberdayaan Masyarakat Pendekatan RRA dan PRA, (Surabaya: Visipress Media, 2010), hlm. 122
} 
W awancara baku terbuka merupakan wawancara yang menggunakan seperangkat perrtanyaan baku. Wawancara ini dibagi menjadi empat, antara lain yaitu: wawancara oleh tim atau panel, wawancara tertutup dan wawancara terbuka, wawancara riwayat secara lisan, serta wawancara terstruktur dan tak terstruktur. Wawancara terstruktur adalah wawancara yang pewawancaranya menetapkan sendiri masalah dan pertanyaan-pertanyaan yang akan diajukan. Sedangkan wawancara tak terstruktur biasanya pertanyaannnya tidak disusun terlebih dahulu, tapi disesuaikan dengan keadaan dan ciri yang unik dari responden. ${ }^{3}$ Selain itu, menurut Masykuri, wawancara tak terstruktur bersifat luwes; susunan pertanyaan dan susunan kata-kata dalam setiap pertanyaannya dapat diubah pada saat wawancara, disesuaikan dengan kebutuhan dan kondisi saat wawancara, termasuk karakteristik sosial budaya (agama, suku, gender, usia, tingkat pendidikan, pekerjaan dan sebagainya) responden yang dihadapi. ${ }^{4}$

Dalam penelitian pemberdayaan masyarakat terkait pengembangan pendidikan karakter remaja Islam di Pringu Bululawang Malang ini, peneliti menggunakan wawancara tak terstruktur. Peneliti mengadakan wawancara dengan kepala desa, perangkat desa, tokoh agama, dan tokoh masyarakat. Pelaksanaan wawancara dilakukan dengan masing-masing informan tersebut dalam waktu yang berbeda. Informan tersebut memiliki latar belakang yang berbeda baik usia, pendidikan, maupun pekerjaan di luar jabatan pemerintahan yang dipertanggungjawabkan. Wawancara yang dilakukan peneliti dilaksanakan dengan tanya jawab yang mengalir seperti percakapan sehari-hari, tetapi peneliti tetap dapat meluruskan pembicaraan dan senantiasa mengingat tujuan wawancara. M etode ini digunakan oleh peneliti untuk mencari data tentang strategi pemetaan pemberdayaan masyarakat, strategi perencanaan pemberdayaan masyarakat, dan strategi pengelolaan pemberdayaan masyarakat dalam pengembangan pendidikan karakter remaja Islam di Pringu Bululawang.

A nalisis data dalam penelitian ini menggunakan analisis data kualitatif deskriptif. M enurut Bogdan dan Biklen, analisis data kualitatif adalah upaya yang dilakukan dengan jalan bekerja dengan data, mengorganisasikan data, memilah-milahnya menjadi satuan yang dapat dikelola, mensintesiskannya, mencari dan menemukan

\footnotetext{
${ }^{3}$ Moleong, Metodologi Penelitian..., hlm. 186-191

${ }^{4}$ Masykuri Bakri, Dekonstruksi Jalan Terjal Pembangunan Negara Dunia Ketiga Perspektif Pendidikan, Pemberdayaan, dan Pelayanan Publi, (Surabaya: Visipress Media, 2009), hlm. 154
} 
pola, menemukan apa yang penting dan apa yang dipelajari, dan memutuskann apa yang dapat diceritakan kepada orang lain. ${ }^{5}$

Penelitian pemberdayaan masyarakat dalam pengembangan pendidikan karakter remaja Islam Pringu Bululawang M alang ini analisis datanya menggunakan model "metode perbandingan tetap". Dinamakan metode perbandingan tetap atau constant comparative method karena dalam analisis data, secara tetap membandingkan satu datum dengan datum lain, kemudian secara tetap membandingkan dengan kategori lainnya. M etode analisis data ini dinamakan juga grounded research, karena awal mulanyaditemukan oleh Glaser dan Stratuss dan dikemukakan dalam buku mereka The Discovery of Grounded Research. Perlu dipahami bahwa grounded research di artikan sebagai filosofi namun juga sebagai metode analisis data.

Secara umum, proses analisis datanya mencakup: reduksi data, kategorisasi data, sintesis, dan diakhiri dengan menyusun hipotesis kerja. Reduksi data adalah identifikasi satuan (unit). Pada mulanya diidentifikasikan adanya satuan yaitu bagian terkecil yang ditemukan dalam data yang memiliki makna bila dikaitkan dengan fokus dan masalah penelitian. Sesudah satuan diperoleh, langkah berikutnya adalah membuat koding. Membuat koding berarti memberikan kode pada setiap 'satuan', agar supaya tetap dapat ditelusuei data/satuannya, berasal dari sumber mana.

Kategorisasi adalah upaya memilah-milah setiap satuan ke dalam bagian-bagian yang memiliki kesamaan. Setiap kategori diberi nama yang disebut label. A dapun mensintesiskan berarti mencari kaitan antara satu kategori dengan kategori lainnya. Kaitan satu kategori dengan kategori lainnya diberi nama atau label lagi.

M enyusun Hipotesis Kerja dilakukan dengan jalan merumuskan suatu pernyataan yang proporsional. Hipotesis kerja ini sudah merupakan teori substantif (yaitu teori yang berasal dan masih terkait dengan data). ${ }^{6}$

A nalisis data dalam penelitian pemberdayaan masyarakat terkait pengembangan pendidikan karakter remaja Islam di pringu Bululawang ini peneliti menggunakan metode perbandingan tetap yang meliputi reduksi data, kategorisasi, sintesisasi, dan menyusun hipotesis kerja.

\footnotetext{
${ }^{5}$ Moleong, J. Lexy, Metodologi Penelitian..., hlm. 248

${ }^{6} \mathrm{Ibid}, \mathrm{hlm} .288-289$
} 
Pada tahap reduksi data, peneliti mengidentifikasi data yang mempunyai makna bila dikaitkan dengan fokus penelitian, yaitu strategi pemetaan pemberdayaan masyarakat, strategi perencanaan pemberdayaan masyarakat, dan strategi pengelolaan pemberdayaan masyarakat dalam pengembangan pendidikan karakter remaja Islam di Pringu bululawang $M$ alang. Kemudian peneliti memberi kode pada setiap satuan atau data baik yang didapat melalui wawancara, observasi, maupun dokumentasi.

Pada tahap kategorisasi, peneliti melakukan pemilahan pada satuan-satuan data ke dalam bagian-bagian yang memiliki kesamaan dalam kaitannya dengan fokus penelitian meliputi strategi pemetaan, perencanaan, dan pengelolaan pemberdayaan masyarakat dalam pengembangan pendidikan karakter remaja Islam di Pringu Bululawang. Adapun pada tahap sintesisasi, peneliti mencari kaitan antara satu kategori dengan kategori lainnya meliputi kaitan antara kategori dalam pemetaan pemberdayaan masyarakat dengan perencanaan pemberdayaan masyarakat, kemudian perencanaan pemberdayaan masyarakat dengan pengelolaan pemberdayaan masyarakat dalam pengembangan pendidikan karakter remaja Islam di Pringu Bululawang M alang.

Pada tahap menyusun hipotesis kerja, peneliti merumuskan suatu pernyataan antara teori yang berkaitan dengan fokus penelitian dengan data yang didapatkan meliputi strategi pemetaan, strategi perencanaan, dan strategi pengelolaan pemberdayaan masyarakat dalam pengembangan pendidikan karakter remaja Islam di Pringu Bululawang Malang dan sekaligus menjadi jawaban fokus penelitian.

Pengecekan terhadap data tentang pemberdayaan masyarakat dalam pengembangan pendidikan karakter remaja Islam Pringu Bululawang Malang ini dilakukan dengan langkah-langkah sebagai berikut: (1) M engecek metodologi yang digunakan untuk memperoleh data; (2) Mengecek kembali hasil laporan yang berupa uraian data dan hasil interpretrasi penulis tentang Pengembangan Pendidikan Karakter Remaja Islam di Pringu Kabupaten Malang; (3) Triangulasi, yaitu teknik pemeriksaan keabsahan data yang memanfaatkan sesuatu yang lain di luar data itu untuk keperluan pengecekan atau sebagai pembanding terhadap data tersebut. ${ }^{7}$ Teknik ini digunakan guna menjamin objektivitas dalam memahami dan menerima informasi, sehingga hasil studi akan lebih objektif. Metode ini

${ }^{7}$ Ibid, hlm. 330 
tampaknya lebih cermat dan jika dilakukan secara sempurna data yang diperoleh akan sulit dibantah sebab didukung oleh cross check sehingga hasilnya lebih dapat dipertanggungjawabkan.

Teknik triangulasi yang digunakan dalah Triangulasi Sumber. Triangulasi sumber, berarti membandingkan dan mengecek balik derajat kepercayaan suatu informasi yang diperoleh melalui waktu dan alat yang berbeda dalam penelitian kualitatif. ${ }^{8}$ Cara ini dilakukan dengan membandingkan data hasil pengamatan dengan data hasil wawancara, membandingkan hasil wawancara dengan dokumen yang berkaitan. Pada teknik ini, langkah pertama yang dilakukan peneliti adalah mengamati pemberdayaan masyarakat dalam pengembangan pendidikan karakter remaja Islam di Pringu. Langkah berikutnya, peneliti mengadakan wawancara mengenai pemberdayaan masyarakat dalam pengembangan pendidikan karaker remaja Islam di Pringu dengan informan yang sudah ditentukan oleh peneliti yaitu kepala desa, perangkat desa, tokoh agama, dan tokoh masyarakat. Selanjutnya, peneliti mengambil dokumen yang berkaitan dengan pemberdayaan masyarakat meliputi kondisi desa, kondisi dan ciri geologis wilayah, sejarah desa, demografis atau kependudukan, visi misi,tujuan, strategi, dan kebijakan, kondisi pemerintahan desa, dan pendidikan.

\section{KERANGKA TEORI}

\subsection{Konsep Tentang Pemberdayaan Masyarakat}

\subsubsection{Pengertian Pemberdayaan}

Huraerah menjelaskan bahwa pemberdayaan berasal dari bahasa Inggris "empowerment" yang secara harfiah bisa diartikan sebagai "pemberkuasaan", dalam arti pemberian atau peningkatan "kekuasaan" (power) kepada masyarakat yang lemah atau tidak beruntung. ${ }^{9}$

\subsubsection{Pemberdayaan masyarakat}

Soetarso (2003) menjelaskan bahwa pemberdayaan masyarakat pada hakikatnya mempunyai dua pengertian yang saling berkaitan, yaitu; peningkatan kemampuan,

\footnotetext{
${ }^{8}$ Ibid

${ }^{9}$ Abu Huraerah, Pengorganisasian dan Pengembangan Masyarakat; Model dan Strategi Pembangunan Berbasis Kerakyatan, (Bandung: Humaniora, 2008), hlm. 82
} 
motivasi dan peran semua unsur masyarakat agar dapat menjadi sumber yang langgeng untuk mendukung semua bentuk usaha kesejahteraan sosial; pemanfaatan sumber masyarakat yang telah ditingkatkan kemampuan, motivasi dan perannya. ${ }^{10}$

\subsubsection{Perencanaan Partisipatif}

Beberapa faktor perencanaan pembangunan, antara lain: (a) Kualitas substansi itu sendiri yang meliputi mekanisme/proses perencanaan rencana, seperti pelaksanaan dialog dan konsultasi publik dengan masyarakat, dan (b) pelaksanaan rencana. Pengembangan dan pemberdayaan masyarakat melibatkan perencanaan, pengorganisasian, dan pengembangan berbagai aktivitas program yang bertujuan untuk meningkatkan taraf hidup atau kesejahteraan sosial masyarakat.

Setiap perencanaan partisipatif disusun mengikuti tahapan atau siklus tertentu. Secara garis besar, perencanaan partisipatif dirumuskan menjadi lima tahap sebagai berikut: (a) identifikasi masalah; (b) Tujuan; (c) penyusunan dan pengembangan perencanaan partisipatif; (d) pelaksanaan; (e) monitoring dan evaluasi (monev). ${ }^{11}$

\subsubsection{Pengertian "Masyarakat" dalam Pendidikan Berbasis Masyarakat}

Terma masyarakat merupakan alih bahasa dari society atau community. Society sering diartikan sebagai masyarakat umum, sedangkan community adalah masyarakat setempat atau paguyuban. Pengertian leksikal di atas mengisayaratkan bahwa community biasanya dimaknai sebagai suatu kelompok manusia yang mendiami suatu wilayah tertentu dengan segala ikatan dan norma di dalamnya. Dengan redaksi berbeda, Orden C. Smucker mencoba mendekati pendidikan dengan persepektif masyarakat (community approach to education). Ia mendefenisikan community sebagai suatu kumpulan populasi, tinggal pada suatu wilayah yang berdekatan, terintegrasi melalui pengalaman umum, memiliki sejumlah institusi pelayanan dasar, menyadari akan kesatuan lokal, dan mampu bertindak dalam kapasitas suatu korporasi. ${ }^{12}$

\footnotetext{
${ }^{10} \mathrm{Ibid}, \mathrm{hlm} .82-83$

${ }^{11}$ Ibid, hlm. 67-68

${ }^{12}$ Toto Suharto, Filsafat Pendidikan Islam, (Jogjakarta: Ar-Ruzz Media, 2011), hlm. 175
} 
3.1.5. Teknik Pemberdayaan Masyarakat Particypatory Rural Appraisal (PRA) dalam Perencanaan Pembangunan

Chambers (1996) mengatakan kendala pemberdayaan yang ada karena rendahnya kemampuan masyarakat bidang pendidikan dan modal, ini dapat diatasi dengan pendekatan PRA (Particypatory Rural Appraisal) sebagai bentuk yang lebih partisipatif. Artinya, orang luar lebih berperan sebagai orang yang mengadakan pertemuan, katalisator dan fasilitator yang memungkinkan masyarakat melakukan dan membagi penyelidikan dan analisis tentang mereka sendiri. M emahami desa secara partisipatif menjadi penting karena akan memberikan fasilitas bagi penyelidikan, analisis, penyajian, dan pemahaman tentang masyarakat itu sendiri sehingga mereka dapat mempelajari, menyajikan, dan memiliki hasilnya. ${ }^{13}$

Teori yang digunakan dalam penelitian pemberdayaan masyarakat terkait pengembangan pendidikan karakter remaja Islam di Pringu Bululawang Malang ini adalah teori Huraerah. Huraerah mengatakan. Participatory Rural Appraisal (PRA) adalah konsep yang dikembangkan untuk menjawab berbagai kritik terhadap pola pengembangan program pembangunan pedesaan. Tujuan PRA sebagai satu di antara metode pendekatan pembangunan pedesaan adalah melibatkan masyarakat pedesaan dalam keseluruhan kegiatan pembangunan sehingga bisa menjadikan warga masyarakat sebagai peneliti, perencana, dan pelaksana program pembangunan. ${ }^{14}$

M enurut Huraerah, PRA adalah pengembangan dari berbagai metode partisipatif yang diangkat dari tradisi masyarakat setempat, sehingga bersifat pragmatis karena memiliki keleluasaan untuk menggunakan berbagai teknik dari metode-metode partisipatif lainnya setelah disesuaikan dengan keperluannya. PRA bertujuan memberdayakan masyarakat supaya kebergantungannya kepada pihak luar secara berangsur-angsur berkurang. ${ }^{15}$

Prinsip-prinsip penerapan PRA di antaranya sebagai berikut: (a) Masyarakat dipandang sebagai subyek, bukan obyek; (b) Praktisi berusaha menempatkan posisi sebagai "insider" bukan "outsider"; (c) Dalam menentukan parameter yang standar, lebih baik mendekati benar daripada benar-benar salah; (d) Masyarakat yang membuat peta, model, diagram,pengurutan, memberi angka atau nilai,

\footnotetext{
${ }^{13}$ Masykuri Bakri, Pemberdayaan Masyarakat..., hlm. 47-48

${ }^{14}$ Idem, Pengorganisasian dan..., hlm. 73

${ }^{15}$ Ibid, hlm. 74
} 
mengkaji atau menganalisis, memberikan contoh, mengidentifikasi masalah, menyeleksi prioritas masalah, menyajikan hasil, mengkaji ulang dan merencanakan kegiatan aksi; (e) Pelaksanaan evaluasi, termasuk penentuan indikator keberhasilan dilakukan secara partisipatif

Adapun teknik-teknik PRA meliputi: (a) Uraian data sekunder atau analisa data dasar; (b) Pemetaan prasarana, bangunan, ruangan, sumber daya alam, dan lokasi; (c) Observasi langsung terhadap dinamika social; (d) Analisis pola penggunaan waktu (jadwal sehari-hari); (e) Kalender musim dan profil perubahan; (f) Diskusi kelompok terarah; (g) Profil sejarah; (h) Analisis pola keputusan; (i) Studi kasus atau cerita tentang kehidupan; (j) Bagan hubungan antar pihak (diagram venn); (k) Peta mobilitas klien masyarakat; (I) Pengurutan potensi atau kekayaan; (m) Bagan alur input-output; (n) Pengorganisasian masalah.

\subsubsection{Pendidikan Berbasis M asyarakat}

Pendidikan berbasis masyarakat, menurut Umberto Sihombing, merupakan pendidikan yang dirancang, dilaksanakan, dinilai, dan dikembangkan oleh masyarakat yang mengarah pada usaha menjawab tantangan dan peluang yang ada di lingkungan masyarakat tertentu dengan berorientasi pada masa depan. Dengan kata lain, pendidikan berbasis masyarakat adalah konsep pendidikan "dari masyarakat, oleh masyarakat dan untuk masyarakat". Dengan ini, Sihombing menegaskan bahwa yang menjadi acuan dalam memahami pendidikan berbasis masyarakat adalah pendidikan luar sekolah, karena pendidikan luar sekolah itu bertumpu pada masyarakat, bukan pada pemerintah. Ia dapat mengambil bentuk Pusat Kegiatan Belajar-M engajar (PKBM) yang tumbuh subur dan masyarakat berlomba-lomba untuk mendirikannya.

Pendidikan berbasis masyarakat sesungguhnya bukan hanya dapat dilaksanakan melalui jalur pendidikan nonformal, sebagaimana diungkapkan Sihombing dan Supriadi di atas. UU No.20 Tahun 2003 pasal 13 ayat (1) menyebutkan bahwa" Jalur pendidikan terdiri atas pendidikan formal, nonformal, dan informal yang dapat saling melengkapi dan memperkaya”. Oleh karena itu, pendidikan berbasis masyarakat dapat juga mengambil jalur formal, nonformal, dan informal. ${ }^{16}$

\subsubsection{Tanggung Jawab M asyarakat terhadap Pendidikan I slam}

${ }^{16}$ Toto Suharto, Filsafat Pendidikan..., hlm.185-186 
Masyarakat besar pengaruhnya dalam memberi arah terhadap pendidikan anak, terutama para pemimpin masyarakat atau penguasa yang ada di dalamnya. Pemimpin masyarakat muslim tentu saja menghendaki agar setiap anak dididik menjadi anggota yang taat dan patuh menjalankan agamanya, baik dalam lingkungan keluarganya, anggota sepermainannya, kelompok kelasnya dan sekolahnya. Bila anak telah besar diharapkan menjadi anggota yang baik pula sebagai warga desa, warga kota dan warga negara.

Dengan demikian, di pundak mereka terpukul keikutsertaan membimbing pertumbuhan dan perkembangan anak. Ini berarti bahwa pemimpin dan penguasa dari masyarakat ikut bertanggung jawab terhadap penyelenggaraan pendidikan, sebab tanggung jawab pendidikan pada hakikatnya merupakan tanggung jawab moral dari setiap orang dewasa baik sebagai perseorangan maupun sebagai kelompok sosial. Tanggung jawab ini di tinjau dari segi ajaran Islam, secara implisit mengandung pula tanggung jawab pendidikan. ${ }^{17}$

\subsection{Konsep Tentang Pendidikan Karakter}

\subsubsection{Pengertian Pendidikan Karakter}

Pendidikan adalah seluruh aktivitas atau upaya secara sadar yang dilakukan oleh pendidik kepada peserta didik terhadap semua aspek perkembangan kepribadian, baik jasmani dan ruhani, secara formal, informal dan nonformal, yang berjalan terus-menerus untuk mencapai kebahagiaan dan nilai yang tinggi (baik nilai insāniyyah maupun ilāhiyyah). Sementara itu, istilah karakter yang dalam bahasa Inggris character, berasal dari istilah Yunani charassein yang berarti membuat tajam atau membuat dalam. Karakter juga dapat berarti mengukir. Sifat utama ukiran adalah melekat kuat di atas benda yang diukir. Karena itu, W ardani seperti dikutip Endri Agus Nugraha menyatakan bahwa karakter adalah ciri khas seseorang dan karakter tidak dapat dilepaskan dari konteks sosial budaya sebab karakter terbentuk dalam lingkungan sosial budaya tertentu.

Suyanto mendefinisikan karakter sebagai cara berpikir dan berperilaku yang menjadi ciri khas tiap individu untuk hidup dan bekerja sama, baik dalam lingkup keluarga, masyarakat, bangsa, dan negara. Individu yang berkarakter baik adalah individu yang bisa membuat keputusan dan siap mempertanggungjawabkan tiap akibat dari keputusan yang ia buat. Secara rinci, Agus Prasetyo dan Emusti

${ }^{17}$ Zakiah Daradjat, dkk., Ilmu Pendidikan Islam. (Jakarta: Bumi Aksara, 2008), hlm. 44-45 
Rivashinta mendefinisikan pendidikan karakter sebagai suatu sistem penanaman nilai-nilai karakter kepada peserta didik yang meliputi komponen pengetahuan, kesadaran atau kemauan, dan tindakan untuk melaksanakan nilai-nilai tersebut, baik terhadap Tuhan YME, diri sendiri, sesama, lingkungan, maupun kebangsaan sehingga menjadi manusia insān kāmil. ${ }^{18}$

Pendidikan karakter memiliki makna yang sebangun dengan pendidikan moral, pendidikan budi pekerti, pendidkan akhlak dan pendidikan nilai. Pendidikan karakter merupakan pendidikan nilai luhur yang berakar dari agama, adat istiadat dan budaya bangsa Indonesia dalam rangka mengembangkan kepribadian peserta didik supaya menjadi manusia yang baik. Secara umum, ruang lingkup pendidikan karakter adalah penanaman dan pengembangan nilai, sikap prilaku peserta didik sesuai nilai-nilai budi pekerti luhur. Di antara nilai-nilai yang perlu ditanamkan adalah sopan santun, berdisiplin, berhati lapang, berhati lembut, beriman dan bertakwa, berkemauan keras, bersahaja, bertanggung jawab, bertenggang rasa, jujur, mandiri, manusiawi, mawas diri, mencintai ilmu, menghargai orang lain, rasa kasih sayang, rasa malu, rasa percaya diri, rela berkorban, rendah hati, sabar, semangat kebersamaan, setia, positif, taat azas, takut bersalah, tawakal, tegas, tekun, tepat jajin, terbuka dan ulet. Jika peserta didik telah memiliki karakter dengan seperangkat nilai-nilai budi pekerti di atas, dia diyakini telah menjadi manusia baik.

Tugas pendidikan karakter, selain mengajar mana nilai-nilai kebaikan dan mana nilai-nilai keburukan, justru ditekankan pada langkah-langkah penanaman kebiasaan (habituation) terhadap hal-hal yang baik. Hasilnya, peserta didik diharapkan mempunyai pemahaman tentang makna nilai-nilai kebaikan dan makna nilai-nilai keburukan, mampu merasakan nilai-nilai yang baik dan mau melakukannya. $\mathrm{Hal}$ ini relevan dengan habit atau kebiasaan yang terus-menerus dipraktikkan dan dilakukan. ${ }^{19}$

\subsubsection{U rgensi Pendidikan Karakter}

\footnotetext{
${ }^{18}$ Syamsul Kurniawan, Pendidikan Karakter: Konsepsi \& Implementasinya secara Terpadu di Lingkungan Keluarga, Sekolah, Perguruan Tinggi, dan Masyarakat, (Yogyakarta: Ar Ruzz Media, 2013), hlm. 27-30

${ }^{19}$ Zubaedi, Pendidikan Berbasis Masyarakat, (Yogyakarta: Pustaka Pelajar, 2004), hlm. 4-7
} 
Pembangunan karakter adalah tujuan luar biasa dari sistem pendidikan yang benar. Pendidikan keluarga maupun pendidikan dalam sekolah, orang tua, dan guru tetap sadar bahwa pembangunan tabiat yang agung adalah tugas mereka.

Banyak hasil penelitian yang membuktikan bahwa karakter seseorang dapat memengaruhi kesuksesannya. $\mathrm{Hal}$ ini mengisyaratkan bahwa mutu pendidikan karakter peserta didik sangat urgen untuk ditingkatkan. Dengan pendidikan karakter, menurut Agus Prasetyo dan Emusthi Rivashinta, seorang anak akan menjadi cerdas emosinya. Kecerdasan emosi adalah bekal terpenting dalam menyongsong masa depan, karena dengannya seorang anak akan dapat berhasil dalam menghadapi segala macam tantangan termasuk tantangan untuk berhasil secara akademik. ${ }^{20}$

\subsubsection{Nilai dan Deskripsi Nilai Pendidikan Karakter}

Nilai yang dikembangkan di Indonesia diidentifikasi berasal dari empat sumber. Pertama, agama; kedua, Pancasila; ketiga, budaya; keempat, tujuan Pendidikan Nasional. Berdasarkan keempat sumber nilai tersebut, teridentifikasi sejumlah nilai untuk pendidikan karakter, yakni: (a) religius; (b) jujur; (c) toleransi; (d) disiplin; (e) kerja keras; (f) kreatif; (g) mandiri; (h) demokratif; (i) rasa ingin tahu; (j) semangat kebangsaan; $(\mathrm{k})$ cinta tanah air; $(\mathrm{I})$ menghargai prestasi; $(\mathrm{m})$ bersahabat dan komunikatif; $(n)$ cinta damai; (o) gemar membaca; ( $p$ ) peduli lingkungan; ( $q$ ) peduli sosial; ( $r$ ) tanggung jawab. ${ }^{21}$

\subsubsection{Pusat Pendidikan Karakter}

Pengembangan Karakter merupakan proses seumur hidup. Dengan demikian, pengembangan karakter seorang peserta didik merupakan upaya seumur hidup yang perlu melibatkan pusat-pusat pendidikan karakter, baik lingkungan keluarga, lingkungan sekolah dan perguruan tinggi, serta lingkungan masyarakat. Pusatpusat pendidikan karakter ini harus berjalan secara terintregasi dan terpadu. Orang tua, guru, dosen, tokoh masyarakat, tokoh agama, tokoh adat, dan lain-lain memiliki tanggung jawab yang sama besarnya dalam melaksanakan pendidikan karakter. ${ }^{22}$

\footnotetext{
${ }^{20}$ Kurniawan, Pendidikan Karakter..., hlm. 31-32

${ }^{21} \mathrm{Ibid}, \mathrm{hlm} .41-42$

${ }^{22}$ Ibid, hlm. 42
} 


\subsubsection{U rgensi Pendidikan Karakter di Lingkungan M asyarakat}

Masyarakat belakangan ini menunjukkan gejala kemerosotan moral yang amat parah. Oleh karena itu, pilihan untuk menjadikan masyarakat sebagai pusat pendidikan karakter di samping keluarga dan sekolah tentulah tepat dan mendesak agar bangsa ini tidak terlalu lama menjadi bangsa yang "sakit" sebelum bertambah parah menjadi "kronis", yang pada akhirnya membunuh harapan masa depan bangsa kita. Gejala kemerosotan moral di masyarakat mengindikasikan adanya pergeseran ke arah ketidakpastian jati diri dan karakter bangsa.

Tingginya angka kejahatan di masyarakat, kasus narkoba, di bidang hukum banyak terjadi ketidakadilan hukum, maraknya kasus korupsi, pergaulan bebas di kalangan remaja, sungguh memprihatinkan. Dari berbagai fenomena yang terjadi, masyarakat hendaknya juga dapat mengambil bagian penting dalam proses pendidikan karakter. M asyarakat yang terdiri dari sekelompok atau individu yang beragam akan memengaruhi tumbuh kembang karakter-karakter individu yang ada di lingkungan masyarakat. Jadi, masyarakat juga mempunyai tanggung jawab yang sama dalam mendidik.

\subsubsection{Aspek Penting dalam Pendidikan Karakter di Lingkungan M asyarakat}

Sepantasnya lingkungan masyarakat yang baik dapat melahirkan berbagai kegiatan kemasyarakatan yang mendukung tumbuh kembangnya karakter, seperti peringatan hari besar keagamaan di surau, mushalla atau masjid, taman pendidikan Al Quran, kursus-kursus keislaman, pembinaan ruhani, dan sebagainya. Dengan demikian masyarakat telah memberikan kontribusi positif bagi pendidikan yang ada di sekitarnya. ${ }^{23}$

\subsubsection{Sarana-sarana Pendidikan Karakter di Lingkungan M asyarakat}

Sarana pendidikan karakter lebih luas dibandingkan dengan sarana pendidikan yang berorientasi kognitif saja. Di antara sarana-sarana tersebut antara lain: (a) tempat-tempat ibadah; (b) perpustakaan daerah; (c) organisasi sosial kemasyarakatan; (d) kegiatan-kegiatan kemasyarakatan; (e) media massa.

${ }^{23} \mathrm{Ibid}, \mathrm{hlm} .197-198$ 


\subsubsection{Keteladanan Pemimpin, Tokoh Agama, dan Tokoh M asyarakat}

Keteladanan pemimpin, tokoh agama, dan tokoh masyarakat menjadi suatu hal penting dalam mendukung terselenggaranya pendidikan karakter bagi masyarakat. Karena bagaimana mungkin menginginkan keadaan masyarakat yang berkarakter, sementara pemimpin, tokoh agama, dan tokoh masyarakatnya tidak berkarakter. ${ }^{24}$

\subsubsection{Penanaman Nilai-nilai Karakter di Lingkungan Masyarakat}

\section{a) Religius}

Tempat-tempat ibadah dapat menjadi pusat penyemaian nilai-nilai karakter masing-masing individu masyarakat, khususnya nilai-nilai religius. Masjid, misalnya, dapat menyelenggarakan banyak sekali kegiatan-kegiatan religius, baik bersifat rutin maupun temporer. Kegiatan rutin seperti sholat fardl berjamaah, kultum, kajian kitab yang diselenggarakan setelah sholat maghrib berjamaah, pengajian bulanan, TPA untuk anak-anak yang ingin belajar membaca Alquran, dan lain-lain. Sementara, kegiatan temporer, seperti peringatan hari besar Islam dan kegiatan bulan suci Ramadhan. Di samping kegiatan yang sifatnya spiritual, juga dapat diselenggarakan kegiatan sosial terutama untuk masyarakat sekitar, seperti kunjungan remaja masjid ke panti asuhan, santunan fakir miskin dan anak yatim, sunatan massal, dan sebagainya. Kegiatan-kegiatan di atas diharapkan dapat membentuk karkateristik religius personal atau kelompok jamaah masjid yang religius dan ber-akhlāq alkarimah.

\section{b) Jujur}

Menumbuhkan budaya jujur di kalangan masyarakat memang tidak mudah. Diperlukan contoh teladan dari para pemimpin. Karena itu, kejujuran hendaklah menjadi syarat utama bagi seorang pemimpin. Hal ini karena masyarakat akan menaruh respek kepada pemimpin apabila dia diketahui dan terbukti memiliki kualitas kejujuran yang tinggi. Pemimpin yang memiliki prinsip kejujuran akan menjadi tumpuan harapan dan bahkan menjadi teladan para pengikutnya. Sebaliknya, pemimpin yang tidak jujur atau khianat akan dibenci oleh raktyatnya.

\section{c) Toleransi}

\footnotetext{
Ibid, hlm. 204
} 
Peran tokoh agama dan tokoh masyarakat diperlukan terutama dalam hal mensosialisasikan secara terus menerus kepada warga tentang pentingnya mengakui hak setiap orang. ${ }^{25}$

\section{HASIL PENELITIAN}

Dari hasil penelitian ditemukan bahwaStrategi pemetaan pemberdayaan masyarakat dalam pengembangan pendidikan karakter remaja Islam di Pringu Bululawang meliputi antara lain: (a) pemetaan wilayah. Wilayah Desa Pringu terbagi 24 Rukun Tetangga di dalam 09 Rukun Warga (RW) yang tergabung di dalam 4 Dusun yaitu: Sumbersari, Krajan, Sidodadi, Sidomulyo; (b) pemetaan masalah. Desa Pringu ini cukup beragam, secara umum berkutat seputar masalah akhlak. Di Pringu Krajan, permasalahannya adalah pergaulan bebas, miras, genggengan, dan kurang aktivitas yang positif dan produktif. Untuk di Dusun Sumbersari dan Sidomulyo, tidak begitu terdapat permasalahan karena pemudapemudanya sudah banyak yang mengaji. Untuk di Dusun Sidodadi, permasalahannya adalah kurangnya kesadaran hukum atau suka main hakim sendiri jadi ujungnya sering bertindak anarki; (c) pemetaan potensi sosial (ekonomi, budaya, pendidikan). Pendidikan biasanya akan dapat mempertajam sistematika berpikir atau pola pikir individu, selain mudah menerima informasi yang lebih maju dan tidak gagap teknologi. Adapun peta pendidikan masyarakat Pringu yaitu buta huruf berjumlah 17 (1,3\%), tidak tamat SD 288 (22,5\%), tamat SD-SM P 724 (56,6\%), tamat SM A 199 (15,6\%), tamat Perguruan Tinggi 51 (4\%); (d) pemetaan sarana prasarana. Sarana prasarana tersebut meliputi masjid, mushola, TPQ, pesantren, balai desa, rumah warga, kegiatan kemasyarakatan, organisasi remaja Islam, dan kesenian; (e) pemetaan pendidikan karakter. Pemetaan pendidikan karakter atau nilai-nilai karakter yang akan ditanamkan antara lain religius, jujur, disiplin, toleransi, cinta Tanah Air, cinta damai, rasa ingin tahu, bertanggung jawab, demokratif, komunikatif, kreatif, kerja keras, peduli sosial, semangat kebangsaan, dan gemar membaca.

Sedangkan Strategi Perencanaan Pemberdayaan M asyarakat dalam Pengembangan Pendidikan Karakter Remaja Islam di Pringu Bululawang Malang yaitu: (a) pembentukan pengurus dan pembagian tugas. Pengurus pemberdayaan masyarakat dalam pengembangan pendidikan krakter remaja di sini adalah

${ }^{25} \mathrm{Ibid}, \mathrm{hlm} .207$ 
gabungan atau memanfaatkan kerjasama Takmir Masjid dengan pejabat pemerintahan Desa. Jadi ada takmir, remas, kasun, dan RT yang diberi tugas melaksanakan dan megelola pemberdayaan masyarakat dalam pendidikan karakter remaja; (b) merumuskan program penanganan masalah yang ada. Penyusunan program didasarkan sesuai kebutuhan dan kemampuan yang dimiliki warga masyarakat berkaitan dengan pemberdayaan masyarakat dalam pengembangan pendidikan karakter remaja Islam di Pringu Bululawang Malang; (c) menggali potensi pemberdayaan. Potensi yang digali berupa SD M , sarana prasarana, tenaga, dan dana pengembangan pendidikan; (d) memanfaatkan fasilitas desa dan rumahrumah warga sebagai prasarana pendidikan karakter; (e) menyusun program kegiatan untuk penanaman nilai-nilai pendidikan karakter.

Adapun strategi pengelolaan pemberdayaan masyarakat dalam pengembangan pendidikan karakter remaja Islam di Pringu Bululawang yaitu: (a) mengadakan pertemuan rutin; (b) mensosialisasikan program; (c) menjadikan masyarakat sebagai sumber pembangunan; (d) menjadikan masjid, mushola, balai desa, dan rumah-rumah warga sebagai tempat pendidikan karakter; (e) penanaman nilai karakter melalui kegiatan keagamaan dan kegiatan sosial kemasyarakatan.

\section{PEMBAHASAN}

Dari hasil Penelitian dapat diperjelas bahwa pemberdayaan masyarakat dalam pengembangan pendidikan karakter remaja Islam di Pringu Bululawang ini menggunakan strategi pemetaan, perencanaan, dan pengelolaan pemberdayaan. A dapun pembahasan hasil penelitian tersebut adalah sebagai berikut:

\subsection{Strategi Pemetaan Pemberdayaan Masyarakat dalam Pengembangan Pen- didikan Karakter Remaja Islam}

Strategi pemetaan pemberdayaan masyarakat dilakukan untuk mempermudah mencari data dan informasi dalam pelaksanaan pemberdayaan masyarakat tersebut. Selain itu, pemetaan juga dilakukan untuk menampung dan memfasilitasi partisipasi masyarakat dalam pengembangan pendidikan karakter remaja Islam di Pringu Bululawang M alang.

A dapun strategi pemetaan dalam penelitian strategi pemberdayaan masyarakat dalam pengembangan pendidikan karakter remaja Islam di Pringu Bululawang $\mathrm{Ma}$ lang ini adalah sebagai berikut:

\subsubsection{Pemetaan W ilayah atau Lokasi}


Pemetaan wilayah merupakan hasil pemetaan sosial yang biasanya berupa suatu peta wilayah yang sudah diformat sedemikian rupa sehingga menghasilkan suatu image mengenai pemusatan karakteristik masyarakat atau masalah sosial, misalnya jumlah orang miskin, rumak kumuh, anak terlantar, yang ditandai dengan warna tertentu sesuai dengan tingkat pemusatannya. ${ }^{26}$ Pemetaan yang dilakukan adalah pemetaan wilayah atau lokasi dengan menerapkan teknik pemetaan sosial untuk pemahaman lingkungan yaitu mendapatkan gambaran karakteristik masyarakat atau masalah sosial dalam pemberdayaan masyarakat.

\subsubsection{Pemetaan M asalah}

Pengorganisasian masalah ditujukan untuk menyusun kembali masalah, menyeleksi masalah, melihat hubungan sebab-akibat dari masalah tersebut, mendiskusikan prioritas masalah dan menggalinya, menganalisis alternatif pemecahan masalah, serta analisis data pengembangan potensi sosial. Sementara itu, hasil yang diharapkan diperoleh informasi tentang hasil analisis masalah, identifikasi sebab-akibat, penetapan prioritas, dan proses sosialisasi pengetahuan baru kepada masyarakat dalam pengorganisasian masyarakat. ${ }^{27}$ Perencanaan yang dilakukan adalah identifikasi masalah dengan menerapkan tahapan perencanaan partisipatif yaitu identifikasi masalah untuk mengkaji dan menyeleksi masalah dan kebutuhan serta menganalisis pemecahannya.

\subsubsection{Pemetaan Potensi}

Pemetaan potensi yang ada di Desa Pringu Bululawang M alang meliputi:

a) Pemetaan Ekonomi M asyarakat. Strategi pemetaan pemberdayaan masyarakat dalam pengembangan pendidikan karakter remaja Islam di Pringu Bululawang $M$ alang ini salah satunya adalah pemetaan ekonomi. Adapun hasil dari pemetaan ekonomi tersebut adalah terdapat beragam kondisi ekonomi masyarakat Desa Pringu, yaitu belum sejahtera, sejahtera dan lebih sejahtera;

\footnotetext{
${ }^{26}$ Bakri, Pemberdayaan Masyarakat...,.hlm. 109-110

${ }^{27}$ Harry R. Hikmat, Strategi Pemberdayaan Masyarakat, (Bandung: Humaniora Utama, 2006), .hlm. 223
} 
b) Pemetaan Sosial Budaya Masyarakat. Di Desa Pringu terdapat berbagai macam sosial budaya masyarakat. Sebagai contoh dari masalah ini adalah warga masyarakat yang berada di pedukuhan Sidodadi dan Sidomulya. Keberagaman tersebutlah yang mendorong adanya pemetaan sosial budaya masyarakat sebagai strategi pemetaan pemberdayaan masyarakat dalam pengembangan pendidikan karakter remaja Islam di Pringu Bululawang M alang. Pemetaan sosial (social mapping) partisipatif didefinisiskan sebagai proses memfasilitasi masyarakat dalam melakukan penggambaran situasi masyarakat secara sistematik dalam suatu wilayah tertentu. Melalui pemetaan sosial partisipatif, masyarakat dan fasilitator (orang luar) bersamasama melakukan proses pembelajaran untuk: pertama, melakukan pengumpulan data dan informasi. Kedua, melakukan kajian atas informasi dan fakta yang sudah didapatkan.28

c) Pemetaan Latar Belakang Pendidikan M asyarakat

Pemetaan pemberdayaan masyarakat salah satunya dengan pemetaan latar belakang pendidikan warga masyarakat. Dengan adanya pemetaan tersebut akan memudahkan siapa dan di bidang apa masyarakat tersebut diberdayakan dalam pengembangan pendidikan karakter remaja Islam di Pringu Bululawang.

Pendidikan biasanya akan dapat mempertajam sistematika berpikir atau pola pikir individu, selain mudah menerima informasi yang lebih maju dan tidak gagap teknologi. A dapun peta pendidikan masyarakat Pringu yaitu buta huruf berjumlah $17(1,3 \%)$, tidak tamat SD $288(22,5 \%)$, tamat SD-SM P 724 (56,6\%), tamat SM A 199 (15,6\%), tamat Perguruan Tinggi 51 (4\%).

Dari uraian di atas dapat disimpulkan bahwa pemetaan yang dilakukan adalah pemetaan latar belakang pendidikan dengan teknik pemanfaatan sumber untuk menentukan orang-orang yang akan dilibatkan dan bidangnya dalam pemberdayaan masyarakat.

\subsubsection{Pemetaan Sarana Prasarana}

Pendidikan karakter membutuhkan berbagai macam sarana prasarana. Adapun sarana prasarana pendidikan karakter yang terdapat di Desa Pringu antara lain:

${ }^{28}$ Bakri, Pemberdayaan Masyarakat ..., hlm. 108-109 
a) M asjid. Di Desa Pringu terdapat 4 masjid yang tersebar di 4 Dusun, yaitu di Sumbersari, Krajan, Sidodadi, dan Sidomulyo. Masing-masing masjid tersebut digunakan sebagai salah satu tempat pendidikan karakter remaja Islam Pringu. Kegiatannya ada majelis ta'lim, khatm al-Qur'ān, pengajian, dan acara peringatan hari besar Islam. Husni menyatakan, bila ada waktu sebaiknya diupayakan adanya shalat berjama'ah dengan anak-anak walaupun sehari hanya sekali. Tokoh masyarakat punya peran dalam pelaksanaan pendidikan agama di masyarakat. Aktifitas keagamaan yang menonjol di masyarakat akan menarik anak untuk ikut ambil bagian. Masjid dapat dijadikan pusat kegiatan anak dan remaja tersebut.

b) Musholla. Di Desa Pringu jumlah seluruhnya ada 17 yang tersebar di 4 Dusun. Mushola-mushola ini juga dimanfaatkan sebagai tempat pendidikan karakter remaja Islam. Kegiatan pendidikan karakter yang dilaksanakan di mushol ini adalah sholat jamaah. Selain itu mushola ini digunakan untuk tempat pesantren ramadhan.

c) Pesantren. Pesantren merupakan salah satu tempat dilaksanakannya pendidikan agama Islam. Di Pringu Bululawang ini, pesantren juga merupakan tempat berlangsungnya pendidikan agama Islam. Salah satu pesantren tersebut dan yang termasuk paling besar di Pringu adalah Pesantren Miftachul Huda.

\subsubsection{Pemetaan Pendidikan Karakter}

Secara rinci, Agus Prasetyo dan Emusti Rivashinta mendefinisikan pendidikan karakter sebagai suatu sistem penanaman nilai-nilai karakter kepada peserta didik yang meliputi komponen pengetahuan, kesadaran atau kemauan, dan tindakan untuk melaksanakan nilai-nilai tersebut, baik terhadap Tuhan YME, diri sendiri, sesama, lingkungan, maupun kebangsaan sehingga menjadi manusia insān kāmil. ${ }^{29}$ Lebih lanjut dijelaskan, sepantasnya lingkungan masyarakat yang baik dapat melahirkan berbagai kegiatan kemasyarakatan yang mendukung tumbuh kembangnya karakter, seperti peringatan hari besar keagamaan di surau, mushalla atau masjid, taman pendidikan Alquran, kursus-kursus keislaman, pembinaan ruhani,

${ }^{29}$ Kurniawan, Pendidikan Karakter..., hlm. 27-30 
dan sebagainya. Dengan demikian, masyarakat telah memberikan kontribusi positif bagi pendidikan yang ada di sekitarnya. ${ }^{30}$

Pemetaan pendidikan karakter atau nilai-nilai karakter yang akan ditanamkan antara lain sikap religius, jujur, disiplin, toleran, cinta tanah air, cinta damai, rasa ingin tahu, bertanggung jawab, demokratif, komunikatif, kreatif, kerja keras, peduli sosial, semangat kebangsaan, dan gemar membaca.

\subsection{Strategi Perencanaan Pemberdayaan Masyarakat dalam Pengembangan Pendidikan Karakter Remaja Islam}

Perencanaan, pada hakikatnya, adalah usaha sadar, terorganisasi, terus-menerus dilakukan guna memilih alternatif terbaik dari sejumlah yang ada untuk mencapai tujuan tertentu. ${ }^{31}$ Adapun strategi perencanaan pemberdayaan masyarakat di Pringu antara lain:

\subsubsection{Pembentukan dan Pembagian Tugas Pengurus $M$ asing- $M$ asing $W$ ilayah yang} Terdiri dari Takmir M asjid, Remas, dan Pejabat Pemerintahan Desa.

Dalam kegiatan inilah dibentuk pengurus remas yang nantinya difungsikan untuk memberdayakan masyarakat dalam pengembangan pendidikan karakter remaja Islam di Pringu. Setelah pembentukan pengurus tersebut, disampaikan pula program-program pemberdayaan masyarakat dalam pengembangan pendidikan karakter remaja Islam di Pringu Bululawang Malang. Dalam sosialisasi program ini, para pengurus didelegasikan ke wilayah asal masing-masing untuk kemudian mensosialisasikan kembali program-program pemberdayaan masyarakat dalam pengembangan pendidikan karakter remaja I slam di wilayahnya tersebut.

Sosialisasi program berikutnya adalah sosialisasi di pesantren. Adapun langkah yang dilakukan adalah dengan menyampaikan program pada masyarakat terutama pada warga masyarakat Pringu yang menjadi wali santri dan alumni pesantren. Cara untuk melakukan sosialisasi tersebut dengan cara mengundang mereka ke pesantren.

5.2.2. M erumuskan Program Penanganan $M$ asalah yang $A$ da

\footnotetext{
${ }^{30}$ Ibid, hlm. 197-198

${ }^{31}$ Abu Huraerah, Pengorganisasian dan..., hlm. 66
} 
Perencanaan yang dilakukan adalah penyusunan program dengan menerapkan penyusunan pola rencana yang komprehensif. Pola tersebut menyangkut strategistrategi, tugas-tugas, dan prosedur-prosedur yang ditujukan untuk membantu kebutuhan-kebutuhan dan pemecahan masalah.

5.2.3. Menggali Potensi Pemberdayaan yang Ada dalam Masyarakat Sebagai Penunjang Pendidikan Karakter

Strategi perencanaan yang dilakukaan adalah identifikasi potensi yang dalam tahapan ini ada kaitannya dengan permasalahan dan kebutuhan serta pemanfaatan sumber daya yang ada.

5.2.4. Memanfaatkan Fasilitas Desa dan Rumah-Rumah Warga Sebagai Sarana Prasarana Pendidikan Karakter

Tempat-tempat tersebut adalah masjid, musholla, pesantren, balai desa, dan tempat-tempat lain yang bisa dijadikan sebagai wadah pemberdayaan masyarakat seperti rumah-rumah warga yang dijadikan tempat kegiatan keagamaan secara bergilir.

\subsubsection{M enyusun Program Kegiatan untuk Penanaman Nilai Pendidikan Karakter.}

Penyusunan program menjadi salah satu strategi perencanaan pemberdayaan masyarakat di Desa Pringu. Penyusunan program tersebut didasarkan pada kebutuhan dan kemampuan warga masyarakat khususnya dalam hal pengembangan pendidikan karakter remaja Islam di Pringu Bululawang M alang. Penyusunan program melibatkan elemen-elemen yang berkepentingan di bidang pemberdayaan masyarakat dalam pemberdayaan masyarakat dalam pengembangan pendidikan karakter remaja Islam di Pringu Bululawang $\mathrm{M}$ alang.

Merujuk pada strategi perencanaan yang diterapkan di Desa Pringu tersebut terdapat teori yang menjelaskan bahwa setiap perencanaan partisipatif disusun mengikuti tahapan atau siklus tertentu. Secara garis besar, perencanaan dirumuskan menjadi lima tahap sebagai berikut: identifikasi masalah, tujuan, penyusunan dan pengembangan perencanaan partisipatif, pelaksanaan, monitoring dan evaluasi (monev). ${ }^{32}$

${ }^{32}$ Ibid, hlm. 67-71 
Dari uraian di atas, diambil kesimpulan bahwa perencanaan yang dilakukan adalah penyusunan program dengan menerapkan penyusunan pola rencana yang komprehensif. Pola tersebut menyangkut strategi-strategi, tugas-tugas, dan prosedurprosedur yang ditujukan untuk membantu kebutuhan-kebutuhan dan pemecahan masalah. 


\subsection{Strategi Pengelolaan Pemberdayaan Masyarakat dalam Pengembangan Pendidikan Karakter Remaja Islam}

\subsubsection{M engadakan Pertemuan Rutin Antar Pengurus}

Mengenai pertemuan rutin menurut para ahli mengatakan walaupun informasi dapat dilakukan melalui berbagai bentuk media massa baik elektronik maupun cetak, namun informasi langsung wawancara melalui pertemuan-pertemuan pada tingkat lokal (RT, RW, Kelurahan) akan sangat efektif dalam hubungannya dengan pemberdayaan masyarakat. ${ }^{33}$ Pengelolaan yang dilakukan adalah pertemuan rutin dan musyawarah dengan menerapkan sistem informasi langsung pada pertemuanpertemuan tingkat lokal untuk membahas pemberdayaan masyarakat.

\subsubsection{M ensosialisasikan Program dan Memanfaatkan Kegiatan Kemasyarakatan sebagai Wadah Bimbingan M ental}

Sosialisasi program menjadi salah satu strategi pengelolaan pemberdayaan masyarakat. Sosialisasi program ini dilakukan di berbagai tempat yang bisa dijadikan sebagai wadah pemberdayaan masyarakat. Tempat-tempat tersebut adalah masjid, mushola, Pesantren, Balai D esa,dan tempat-tempat lain yang bisa dijadikan sebagai wadah pemberdayaan masyarakat seperti rumah-rumah warga yang dijdikan tempat kegiatan keagamaan secara bergilir.

Sejalan dengan itu, sebelum pelayanan dapat diperoleh, para calon penerima pelayanan harus mengetahui keberadaan lembaga. Assessment kebutuhan dapat mengidentifikasi saluran-saluran formal dan informal yang memungkinkan dijangkaunya pelayanan

Sosialisasi program ini disampaikan pada remaja masjid seluruh Desa Pringu. Adapun langkahnya adalah mengumpulkan remaja masjid seluruh Desa Pringu untuk mengikuti kegiatan bertempat di Masjid Pusat atau Masjid Jami’ Desa Pringu yang terletak di Pringu Krajan. Dalam kegiatan ini, dibentuk pengurus remas yang akan difungsikan untuk memberdayakan masyarakat dalam pengembangan pendidikan karakter remaja I slam di Pringu.

5.3.3. M enjadikan M asyarakat Sebagai Sumber M oril M aupun Materil pada Setiap Kegiatan Pendidikan Karakter

${ }^{33}$ Ibid, hlm. 84 
Strategi pengelolaan dalam pemberdayaan masyarakat ini adalah menjadikan potensi yang bisa digali yang ada di Desa Pringu sebagai sumber moril maupun materil. A dapun potensi yang digali berupa SDM, sarana prasarana, tenaga, dan dana pengembangan pendidikan.

Sejalan dengan pemikiran para ahlibahwa kajian tentang potensi dikaitkan dengan permasalahan atau kebutuhan masyarakat. ${ }^{34}$ Biasanya, akan lebih mudah dimengerti oleh masyarakat jika dihubungkan dengan permasalahan akses masyarakat terhadap fasilitas pendidkan, kesehatan, pasar, kantor desa, lapangan olah raga, dan balai desa. Dengan sendirinya permasalahan akan muncul, misalnya masalah transportasi, jarak yang terlalu jauh, waktu untuk mengakses, fasilitas, tidak tersedianya tenaga yang cukup, dan lain-lain. I dentifikasi potensi dalam masyarakat tersebut difokuskan pada potensi yang bisa digali dan mampu mengembangkan pendidikan karakter remaja Islam di Pringu Bululawang M alang.

Berdasarkan uraian di atas bisa disimpulkan bahwa strategi perencanaan yang dilakukaan adalah identifikasi potensi yang dalam tahapan ini ada kaitannya dengan permasalahan dan kebutuhan serta pemanfaatan sumber daya yang ada.

\subsubsection{M enjadikan Masjid, Mushola, Balai Desa, dan Rumah-Rumah Warga Se- bagai Tempat Pendidikan Karakter}

H usni menyatakan bila ada waktu sebaiknya diupayakan adanya shalat berjama'ah dengan anak-anak walaupun sehari hanya sekali. Tokoh masyarakat punya peran dalam pelaksanaan pendidikan agama di masyarakat. Aktifitas keagamaan yang menonjol di masyarakat akan menarik anak untuk ikut ambil bagian. M asjid dapat dijadikan pusat kegiatan anak dan remaja tersebut.

Tempat-tempat yang digunakan sebagai tempat pendidikan karakter remaja I slam di Pringu Bululawang tersebut adalah masjid, mushola, Pesantren, Balai Desa,dan tempat-tempat lain yang bisa dijadikan sebagai wadah pemberdayaan masyarakat seperti rumah-rumah warga yang dijdikan tempat kegiatan keagamaan secara bergilir.

5.3.5. Penanaman Nilai Karakter M elalui Kegiatan Keagamaan dan Kegiatan Sosial Kemasyarakatan

${ }^{34}$ Hikmat, Strategi Pemberdayaan..., hlm. 226 
Nilai-nilai karakter yang akan ditanamkan antara lain religius, jujur, disiplin, toleran, cinta Tanah Air, cinta damai, rasa ingin tahu, bertanggung jawab, demokratis, komunikatif, kreatif, kerja keras, peduli sosial, semangat kebangsaan, dan gemar membaca.

A dapun kegiatan-kegiatan kemasyarakatan yang juga digunakan sebagai salah satu sarana pendidikan karakter remaja I slam di Pringu Bululawang antara lain:

a) Majelis Dibä'

Salah satu kegiatan remaja Islam yang ada di Pringu Bululawang adalah Dibā' A kbar yang dilaksanakan satu bulan satu kali setiap malam kamis kliwon. Adapun jamaahnya adalah remaja masjid se-Desa Pringu dan bertempat di M asjid Nurul Huda Al-Jaelani Pringu Krajan. Jumlah jamaahnya kurang lebih 60 remaja I slam dari seluruh wilayah Pringu.

b) Majelis Taklim

Menurut Muzayyin, Majelis Taklim merupakan salah satu sentral pembangunan mental keagamaan di lingkungan masyarakat yang berbeda stratifikasi sosiokulturalnya. M ajelis Taklim adalah termasuk lembaga atau sarana dakwah islamiyah yang secara self-standing dan self-disciplined dapat mengatur dan melaksanakan kegiatan-kegiatannya. Di dalamnya berkembang prinsip demokrasi yang berdasarkan musyawarah untuk mufakat demi kelancaran pelaksanaan al-ta'lìm al-islāmì sesuai dengan tuntutan pesertanya.

$M$ ajelis taklim yang ada di Pringu adalah kegiatan remaja masjid. Kegiatan tersebut dilaksanakan satu bulan dua kali setiap hari rabu legi dan rabu kliwon. Jamaahnya adalah remaja I slam di Pringu dan juga para jamaah sholat di masjid biasanya ikut serta dalam acara tersebut. Bentuk kegiatannya ceramah oleh Kyai, kemudian tanya jawab. Untuk Kyainya ada dua bergantian dalam satu bulan yaitu Kyai Hanan dari Blambangan dan Gus Wahyu dari Kasri Bululawang.

Sejalan dengan Majelis Taklim di Desa Pringu ini terdapat teori para ahli menjelaskan M ajelis Taklim yang berkembang sejak zaman Rasulullah. Pada zaman itu, muncul berbagai jenis kelompok pengajian sukarela, tanpa bayaran, yang disebut halāqah yaitu kelompok pengajian di Masjid Nabawi atau M asjid al-Haram. Tempat halāqah biasanya ditandai dengan salah satu 
pilar masjid untuk tempat berkumpulnya peserta kelompok masing-masing dengan seorang sahabat, yaitu ulama terpilih.

Kalangan muslim yang ingin mendalami ilmu pengetahuan tasawuf (mysticism), di sudut-sudut Masjid $\mathrm{N}$ abawi dan $\mathrm{M}$ asjid al-Haram terdapat majelis pengajian yang disebut zäwiyah. Di kalangan anak-anak pada zaman itu juga dikembangkan kelompok pengaijan khusus yang disebut al-Kuttāb yang mengajarkan baca A lquran.

c) M ajelis Khatm al-Qur' $\bar{a} n$

K hatm al-Qur' ān juga merupakan salah satu kegiatan kemasyarakatan remaja Islam di Pringu. Khatm al-Qur'ān dilaksanakan setiap kamis kliwon dan bertempat di masjid. Adapun waktunya dimulai sejak subuh sampai setelah dhuhur. Khatm al-Qur'ān ini dilaksanakan oleh remaja masjid. Selain mendidik remaja masjid untuk gemar membaca Alqur' an, Khatm al-Qur' $\bar{a} n$ ini juga sebagai salah satu sarana penggalian dana remas. Dana tersebut didapatkan dari para warga yang menitipkan shodaqoh khol arwah keluarga mereka masing-masing setiap jadwal Khatm al-Qur'ān.

d) Istighātsah dan Pembinaan M ental

Kegiatan kemasyarakatan sehubungan dengan pendidikan karakter yang lain adalah istighātsah dan pembinaan mental. Istighätsah ini dilaksanakan satu bulan sekali. Adapun jumlah jamaahnya 60 orang yang terdiri dari remaja Islam, RT, RW, dan Perangkat Desa. Istighätsah tersebut bertempat di rumah para jamaah secara bergilir.

e) Tahlil dan Pengajian

Kegiatan kemasyarakatan yang lain adalah tahlil. Pendidikan karakter remaja Islam dalam tahlil ini dilakukan dengan cara menerjunkan anggota remas untuk menjadi imam tahlil dan MC yang terdapat di RT-RT setempat. Kegiatan ini dilakukan satu bulan dua kali setiap kamis malam jumat.

f) $\mathrm{PHBI}$

Kegiatan kemasyarakatan berikutnya adalah PHBI. Tujuan PHBI tersebut selain sebagai salah satu wujud rasa bangga dan penghormatan sebagai umat I slam juga dijadikan sebagai salah satu cara pelaksanaan pendidikan karakter remaja Islam. PH BI yang rutin dilaksanakan antara lain di Bulan M uharram, M aulud, Rajab, Romadlon, Bulan Syawal, dan di Bulan Dzul Hijjah. Adapun 
kegiatan PHBI tersebut antara lain; Peringatan Tahun Baru Islam dan 'Asyura, Peringatan Maulud Nabi Muhammad saw, Peringatan Isro’ Mi'roj, Safari Romadlon, Halal Bihalal, Penyembelihan Qurban.

g) PHBN

Selain $\mathrm{PHBI}$, kegiatan kemasyarakatan yang rutin dilaksanakan adalah Peringatan Hari Besar Nasional (PHBN). PHBN yang dilaksanakan di sini adalah HUT RI. A dapun kegiatan yang dilaksanakan adalah lomba-lomba.

\section{KESIMPULAN}

Kesimpulan dari penelitian ini adalah:

a) Strategi pemetaan pemberdayaan masyarakat dalam pengembangan pendidikan karakter remaja Islam di Pringu Bululawang antara lain yaitu, pemetaan wilayah, pemetaan masalah, pemetaan potensi sosial (ekonomi, budaya, pendidikan), pemetaan sarana prasarana, pemetaan pendidikan karakter.

b) Strategi perencanaan pemberdayaan masyarakat dalam pengembangan pendidikan karakter remaja Islam di Pringu Bululawang Malang yaitu pembentukan pengurus dan pembagian tugas, merumuskan program penanganan masalah yang ada, menggali potensi pemberdayaan, memanfaatkan fasilitas desa dan rumah-rumah warga sebagai prasarana pendidikan karakter, menyusun program kegiatan untuk penanaman nilai-nilai pendidikan karakter.

c) Strategi pengelolaan pemberdayaan masyarakat dalam pengembangan pendidikan karakter remaja Islam di Pringu Bululawang yaitu mengadakan pertemuan rutin, mensosialisasikan program, menjadikan masyarakat sebagai sumber pembangunan, menjadikan masjid, mushola, balai desa, dan rumah-rumah warga sebagai tempat pendidikan karakter, penanaman nilai karakter melalui kegiatan keagamaan dan kegiatan sosial kemasyarakatan. [] 


\section{REFERENCES}

Bakri, Masykuri. 2009. Dekonstruksi Jalan Terjal Pembangunan Negara Dunia Ketiga Perspektif Pendidikan, Pemberdayaan, dan PelayananPublik.Surabaya: Visipress Me

Hikmat, R. Harry. 2006. Strategi Pemberdayaan M asyarakat. Bandung: H umaniora Utama

Huraerah, Abu. 2008. Pengorganisasian dan Pengembangan Masyarakat; Model dan Strategi Pembangunan Berbasis Kerakyatan. Bandung: H umaniora

Kurniawan, Syamsul. 2013. Pendidikan Karakter: Konsepsi \& Implementasinya Secara Terpadu di Lingkungan Keluarga, Sekolah, Perguruan Tinggi, dan M asyarakat. Yogyakarta: Ar Ruzz M edia

Moleong, J. Lexy. 2007. Metodologi Penelitian Kualitatif. Bandung: PT Remaja Rosdakarya.

Toto Suharto. 2011. Filsafat Pendidikan Islam. Jogjakarta: Ar-Ruzz M edia

Zakiah Daradjat, dkk. 2008. IImu Pendidikan Islam. Jakarta: Bumi A ksara

Zubaedi. 2004. Pendidikan Berbasis M asyarakat. Yogyakarta: Pustaka Pelajar 